\title{
PETROLOGY AND PROVENANCE STUDY OF THE QUATERNARY CLASTIC SEDIMENTS FROM HERSO KILKIS (MACEDONIA, GREECE)
}

\author{
Georgiadis I. K. ${ }^{1}$, Tsirambides A. ${ }^{1}$, Kassoli-Fournaraki A. ${ }^{1}$, and Trontsios G. ${ }^{1}$ \\ ${ }^{1}$ Aristotle University of Thessaloniki, School of Geology, Department of Mineralogy-Petrology- \\ EconomicGeology, iogeorgi@geo.auth.gr,ananias@geo.auth.gr,kassoli@geo.auth.gr, \\ trontzos@geo.auth.gr
}

\begin{abstract}
The sediments analysed are generally coarse grained, sand gravels to gravel sands. The silt and clay content of the samples is low and their textural study revealed a fluvial deposition environment. The amounts of quartz, feldspars and lithic fragments range from $33 \%$ to $56 \%$, $8 \%$ to $18 \%$ and $28 \%$ to $52 \%$, respectively. The samples studied may be classified as garnet-mica bearing litharenites. Quartz, plagioclases and micas are the predominant constituents. Detrital calcite and pyroxenes are present in small amounts. The samples are texturally and mineralogically immature. Detailed polarized microscopy revealed the presence of garnet, staurolite, kyanite, zoisite, routile, epidote, zircon, apatite and tourmaline, as well as of opaque minerals. These accessory minerals are considered indexes of metamorphic provenance. Geochemically the samples are classified as sublitharenites and subarkoses, all being rich in $\mathrm{SiO}_{2}$. The overall percentages of quartz, feldspars and rock fragments designate intense physical weathering and rapid transport and deposition in the Herso Basin which is part of a passive continental margin (recycled orogen).
\end{abstract}

Key words: drilling cuttings, paragenesis, mineral indexes, origin.

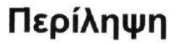

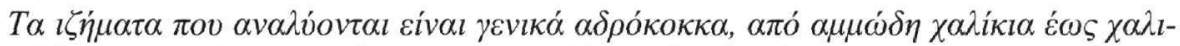

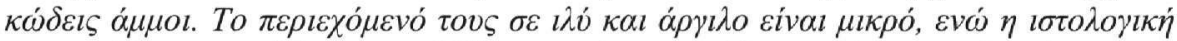

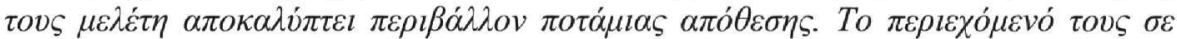

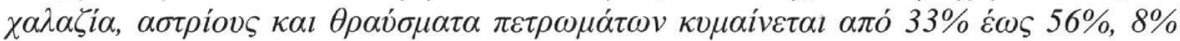

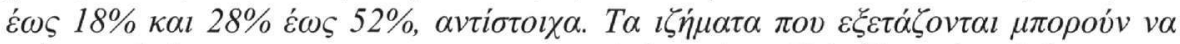

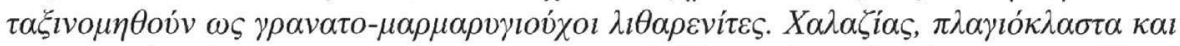

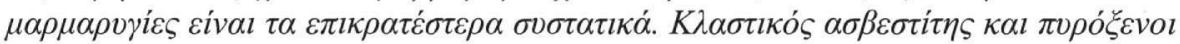

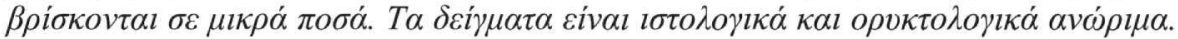

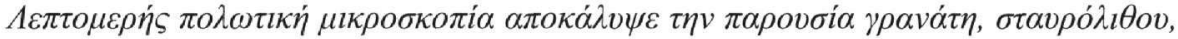

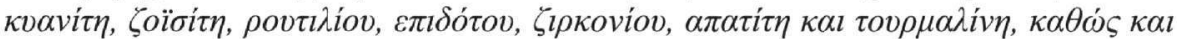

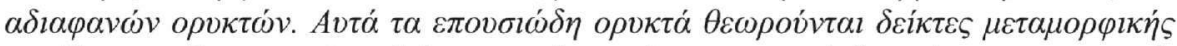

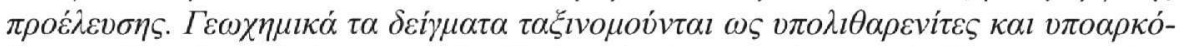

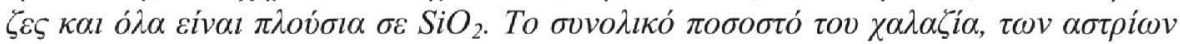

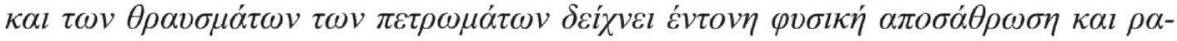




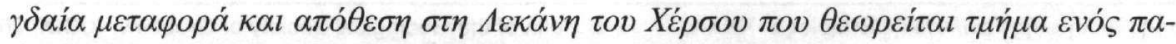

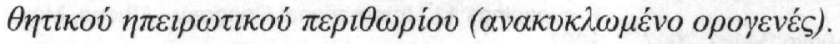

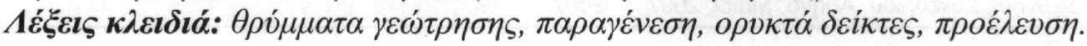

\section{Introduction}

The Neogene and Quaternary sediments, along with the molassic sediments of Eocene-Miocene of Greece lie unconformably over the folded alpine basement and are of fluvial, lacustrine or marine origin. Especially, the Neogene and Quaternary sediments are deposited into grabens or other neotectonic basins and are not connected to orogenetic procedures. The Post Alpine formations are widespread and are characterized by a wide lithological and facies variation (Mountrakis 1985).

The sediments studied were deposited into the Axios-Thessaloniki neotectonic graben, overlying the alpine basement and the Tertiary molasses. The graben has a NNW-SSE general direction and the detrital sediments filling it are generally loose alluvial, fluvial and lacustrine formations (mainly sandstones). These formations are medium to coarse grained gravel sands to gravel mud sands, moderately to poorly sorted and rich in feldspars and quartz (Mountrakis et al. 1993, Tsirambides 1997).

Dott (1964) supports that textural maturity and compositional stability provide the clearest guides in the sandstone classification. In general, sandstones are classified into arkoses, litharenites, greywackes and quartz arenites. Arkoses are terrigenous coarse grained sandstones formed from intense physical weathering of granites and gneisses and rapid transport and deposition of the clastic materials at small distance. They generally contain abundant feldspars $(>25 \%)$, usually altered and are mineralogically and texturally immature. Litharenites are sandstones with a great mineralogical diversity, rich in rock fragments and quartz with a lesser amount of feldspars than arkoses and significant amount of detrital mica. The litharenites are indicators of relatively adjacent provenance. Greywackes are marine sandstones and quartz arenites are mineralogically mature cratonic sandstones (Pettijohn et al. 1973). In arkoses, the clay fraction is a minor constituent, whereas in quartz sandstones the sand fraction is abundant in detrital quartz (Blatt et al. 1972).

This study considers the detailed mineralogical and chemical study of clastic sediments from the Herso Basin (Kilkis Prefecture). Using a variety of petrographic, mineralogical and geochemical techniques it is attempted to elucidate the processes under which these sediments were formed and the parent rocks which constitute the supplier of these clastic materials.

\section{Geological Setting}

The Herso Basin is located approximately $13 \mathrm{~km} \mathrm{N-NW}$ of the city of Kilkis. It has an elongated shape, covers an area of approximately $100 \mathrm{~km}^{2}$, and it is drained mainly from Doiranis River and several torrents. Serbomacedonian Massif constitutes the eastern margin of the Basin (Disoro Mountain), whereas Circum Rhodope Belt constitutes the western margin (Fig. 1). The Quaternary detrital sediments under study overlie unconformably the alpine basement (I.G.M.E. 1990).

The eastern margin of Herso Basin (Disoro Mountain) constitutes the western part of the Serbomacedonian Massif. Disoro Mountain, being a part of the Vertiskos Unit, consists of the following Paleozoic metamorphic rocks: a) medium grained pelitic mica schists rich in quartz, micas and to a lesser extent plagioclase and metamorphic minerals (mainly garnet altered to chlorite, kyanite, clinozoisite and staurolite); b) meta-arkosic rocks rich in quartz, plagioclase, micas, apatite, titanite and opaque minerals; c) coarse augen gneiss comprised of quartz, feldspars, biotite, zoisite, epidote, apatite, zircon and opaque minerals; and d) banded amphibolites. In all the petrographic types the plagioclase is usually altered to sericite. In addition, Paleozoic ultramafic rocks are present in small bodies, mainly consisting of serpentine, accessory titanite and opaque minerals. Finally, a Mesozoic granite is found tectonically emplaced between Serbomacedonian 
Massif and Circum Rhodope Belt at the North part of the Basin. This granite is mainly composed of quartz, perthitic microcline, plagioclase, chloritized biotite and zircon, allanite, apatite, fluorite and titanite as accessory minerals. Hydrothermal alteration of the constituents of this granite is very evident (Sidiropoulos 1991, Christofides et al. 1999).

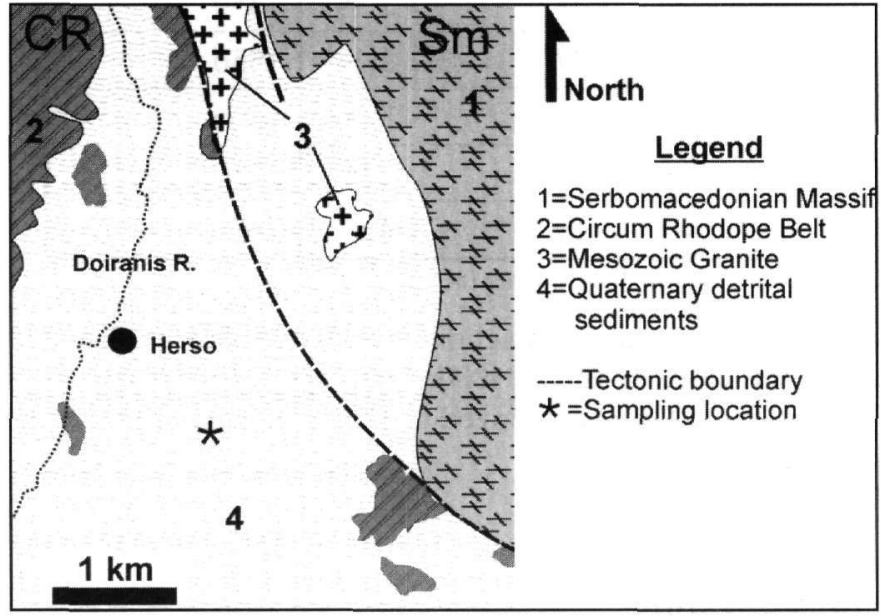

Figure 1 - Petrographic sketch map of the Herso Basin

The western margin of Herso Basin (Mavros Vrahos and Megali Toumpa Hills) actually is the eastern boundary of the Circum Rhodope Belt. The latter generally consists of Permotriassic volcanic rocks and meta-clastic sediments which are accompanied by Mesozoic sediments (Doumbia Unit). It is a succession of Permian turbidity meta-clastics (Examili Formation) comprised of meta-sandstones, quartzites and breccias in the lower part, a Permotriassic volcanisedimentary series with alternating acid volcanics and meta-clastics in the middle and Mesozoic neritic and marine carbonates in the upper part. Usually, the above mentioned formations show silicification and are schistosed (Asvesta 1992).

\section{Materials and Methods}

From different horizons of a water drilling performed to a depth of $150 \mathrm{~m}, 16$ cutting samples were taken. They were analyzed in detail by the use of X-ray diffraction (XRD), polarizing microscopy and geochemical techniques. The samples were separated into consecutive size fractions by sieving in order their textural properties to be studied. Prior to the mineralogical analysis the collected samples were disaggregated by the use of an agate mortar and pestle, gently in order to retain to the extent possible their intrinsic grain sizes. The fraction of $0.5-1 \mathrm{~mm}$ was chosen for the $\mathrm{X}$-ray diffraction, microscopical and geochemical study, due to its extended abundance in all samples.

X-ray diffraction was performed on a Philips diffractometer with Ni-filtered $\mathrm{CuK}_{\alpha}$ radiation. Randomly oriented mounts of the untreated fraction of $0.5-1 \mathrm{~mm}$ of the samples were scanned over the interval $3-43^{\circ} 2 \theta$ at a scanning speed $1^{\circ}$ per minute. Semi-quantitative estimates of the minerals present are based on peak heights and intensity factors on XRD patterns, without the employment of any correction factors (Table 1), using the methods described by Schultz (1964), Cook et al. (1975) and Tsirambides (2004).

Polarizing microscopy analysis was performed by the use of thin sections prepared from grains of the fraction $0.5-1 \mathrm{~mm}$ of each sample. In this way the paragenesis of the samples was determined in detail. In addition, the thin sections were point counted in order the percentages of monocrystalline and polycrystalline quartz, feldspars and lithic fragments as well as of all minerals present to be calculated and the samples to be classified. 
Table 1 - Peak heights used for mineral semi-quantitative determination (Tsirambides 2004)

\begin{tabular}{|l|l|l|l|}
\hline \multicolumn{1}{|c|}{ Mineral } & Angle (20) & $\mathbf{d}(\AA)$ & Counts/second \\
\hline Quartz & 20.8 & 4.26 & 765 \\
\hline Plagioclase & 28.0 & 3.18 & 1350 \\
\hline Alkali feldspar & 27.5 & 3.24 & 1350 \\
\hline Calcite & 29.4 & 3.04 & 1370 \\
\hline Pyroxene & 29.9 & 2.99 & 1250 \\
\hline Total micas ${ }^{1}$ & 19.7 & 4.50 & 260 \\
\hline
\end{tabular}

The geochemistry of the above mentioned fraction of each sample was also studied. The chemical analysis was performed on a Perkin Elmer 5000 flame spectrometer apparatus. Quantity of the fraction $0.5-1 \mathrm{~mm}$ of each sample was pulverized and the major oxides were measured by the use of atomic absorption spectrometry (AAS).

\section{Results}

\subsection{Lithology and Petrology}

The samples analysed are generally coarse grained, sand gravels to gravel sands. All samples present unimodal frequency curves except $\mathrm{X} 1, \mathrm{X} 2$ and $\mathrm{X} 10$ that show bimodal patterns and poorer sorting. All grains present low sphericity and are angular to subangular. The lithic fragments which are constituted of finer quartz grains are generally more rounded than those constituted of coarser quartz grains. The same trend is noticed for these lithic fragments constituted of fine white mica embracing altered metamorphic minerals. Finally, the single crystals of metamorphic minerals (i.e. garnet, kyanite and staurolite) are present as euhedral crystals with more angular shape (Georgiadis 2006). All samples are texturally and mineralogically immature. The silt and clay content of the samples is low (generally $<15 \%$ ) and their textural study revealed a fluvial deposition environment, except for the sample X3 ( 70 m depth) which is lacustrine.

Table 2 - Main constituents (wt. \%) of the samples analysed

\begin{tabular}{|l|l|c|c|c|l|l|l|l|l|}
\hline Sample & Depth (m) & Q & F & L & Sample & Depth $(\mathbf{m})$ & Q & F & L \\
\hline X1 & 0.15 & 33 & 15 & 52 & X9 & $102-108$ & 54 & 18 & 28 \\
\hline X2 & $40-46$ & 42 & 15 & 42 & X10 & $108-114$ & 56 & 8 & 37 \\
\hline X3 & $66-72$ & 43 & 16 & 41 & X11 & $114-120$ & 48 & 12 & 39 \\
\hline X4 & $78-84$ & 48 & 16 & 36 & X12 & $120-126$ & 52 & 10 & 38 \\
\hline X5 & $84-90$ & 50 & 11 & 39 & $X 13$ & $126-132$ & 51 & 15 & 34 \\
\hline X6 & $90-94.5$ & 52 & 14 & 34 & X14 & $132-138$ & 50 & 12 & 39 \\
\hline X7 & $94.5-96$ & 54 & 10 & 36 & X15 & $138-144$ & 48 & 11 & 41 \\
\hline X8 & $96-102$ & 52 & 12 & 36 & X16 & $144-150$ & 46 & 17 & 38 \\
\hline
\end{tabular}

$\mathrm{Q}=$ monocrystalline and polycrystalline quartz, $\mathrm{F}=$ feldspars and $\mathrm{L}=$ lithic fragments

Table 2 presents the percentages of monocrystalline and polycrystalline quartz, feldspars and lithic fragments of the samples studied. These are classified as litharenites and feldspathic litharenites according to Folk et al. (1970) and Pettijohn et al. (1973). Generally, the amounts of quartz, feldspars and lithic fragments range from $33 \%$ to $56 \%, 8 \%$ to $18 \%$ and $28 \%$ to $52 \%$, respectively. According to Tucker (2001) the samples are mineralogically immature due to their 
high content in lithic fragments and feldspars, indicative of an adjacent source of the clastic load. The litharenites definitely designate a surface weathering mainly of volcanic, sedimentary and low grade metamorphic rocks, the latter reflected in their mineral constituents (Pettijohn et al. 1973).

\subsection{Mineralogy}

The X-ray diffraction semiquantitative determination of the samples is shown in table 3. Quartz is the predominant constituent of the samples. This is due to its abundance in the surrounding metamorphosed rocks, to its mechanical resistance, as well as to the chosen fraction studied (Blatt 1992). The amount of quartz in the samples shows an increasing trend up to the depth of approximately $90 \mathrm{~m}$, and then remains above $70 \%$ in the deeper ones.

Plagioclase is the second in abundance mineral after quartz, with the exception of sample X1. Alkali feldspar is always present in minor amounts. According to Blatt (1992) feldspars constitute the $10-15 \%$ of sandstones, a general rule that seems to apply in the studied samples. Even though the plagioclases are considered less stable in weathering compared to the alkali feldspars, in all samples studied the plagioclases are more abundant than the alkali feldspars. This is due to intense weathering of the parent rocks and to the rapid transport and deposition of the clastic materials at small distance. Plagioclase content along the depth of the drilling shows exactly the opposite trend compared to that of the quartz, whereas no distinct trend is obvious for the alkali feldspar.

Table 3 - Mineralogical composition (wt. \%) of the samples analysed

\begin{tabular}{|l|l|l|l|l|l|l|l|l|l|l|l|l|l|}
\hline Sample & $\mathbf{Q}$ & $\mathbf{P 1}$ & $\mathbf{K f}$ & $\mathbf{M}$ & $\mathbf{C}$ & $\mathbf{P x}$ & Sample & $\mathbf{Q}$ & $\mathbf{P I}$ & $\mathbf{K f}$ & $\mathbf{M}$ & $\mathbf{C}$ & $\mathbf{P x}$ \\
\hline $\mathrm{X} 1$ & 58 & 14 & 6 & 22 & $\mathrm{nd}$ & $\mathrm{nd}$ & $\mathrm{X} 9$ & 80 & 8 & 8 & 4 & tr & tr \\
\hline $\mathrm{X} 2$ & 70 & 18 & 4 & 6 & 1 & 1 & $\mathrm{X} 10$ & 82 & 9 & 3 & 6 & $\mathrm{nd}$ & $\mathrm{nd}$ \\
\hline $\mathrm{X} 3$ & 68 & 15 & 3 & 11 & 1 & 2 & $\mathrm{X} 11$ & 83 & 9 & 5 & 3 & $\mathrm{tr}$ & $\mathrm{tr}$ \\
\hline $\mathrm{X} 4$ & 75 & 12 & 3 & 8 & $\mathrm{tr}$ & 2 & $\mathrm{X} 12$ & 76 & 12 & 9 & 3 & $\mathrm{tr}$ & $\mathrm{tr}$ \\
\hline $\mathrm{X} 5$ & 67 & 12 & 14 & 6 & 2 & 1 & $\mathrm{X} 13$ & 84 & 9 & 5 & 2 & tr & $\mathrm{nd}$ \\
\hline $\mathrm{X} 6$ & 86 & 7 & 1 & 5 & $\mathrm{nd}$ & 1 & $\mathrm{X} 14$ & 78 & 11 & 8 & 3 & $\mathrm{nd}$ & $\mathrm{nd}$ \\
\hline $\mathrm{X} 7$ & 84 & 8 & 4 & 4 & tr & tr & $\mathrm{X} 15$ & 82 & 10 & 5 & 3 & $\mathrm{nd}$ & $\mathrm{nd}$ \\
\hline $\mathrm{X} 8$ & 84 & 9 & 3 & 4 & $\mathrm{nd}$ & tr & $\mathrm{X} 16$ & 78 & 12 & 5 & 5 & $\mathrm{nd}$ & $\mathrm{nd}$ \\
\hline
\end{tabular}

$\mathrm{Q}=$ quartz, $\mathrm{Pl}=$ plagioclase, $\mathrm{Kf}=$ alkali feldspar, $\mathrm{M}=$ mica, $\mathrm{C}=$ detrital calcite, $\mathrm{Px}=$ pyroxene, $\mathrm{tr}=$ traces and $\mathrm{nd}=$ not detected

In all samples mica is present mostly as muscovite. Its increased abundance is due to its extended presence in the adjacent metamorphic parent rocks. Chlorite was also detected in traces in all samples. Generally, the mica content of the samples decreases downwards and below approximately $90 \mathrm{~m}$ is practically constant and less than $6 \%$.

Detrital calcite was detected in minor amounts $(<2 \%)$ in most of the samples. Almost in all samples pyroxene was found in amounts from traces up to $3 \%$, with a decreasing tendency to the deeper horizons. In the sample X2 traces of garnet (with almandine composition) were found and in the sample X8 traces of hematite were detected, too. The presence of garnet and pyroxene reveals a metamorphic provenance for the clastic sediments studied, whereas hematite may have formed from the alteration of the opaque minerals of the metamorphic parent rocks (Blatt 1992, Deer et al. 1998).

The samples are mineralogically immature since they contain great amounts of feldspars and ferromagnesian minerals (i.e. micas and pyroxenes). Because the clastic sediments under study contain these vulnerable to weathering minerals, it may be assumed that these were deposited near their source origin (Pettijohn et al. 1973, Sawyer 1986, Tsirambides 2004). 
The samples studied may be classified as garnet-mica bearing litharenites according to Folk et al. (1970).

From the detailed polarized microscopy study, the following results were taken concerning the composition of the studied samples:

Their paragenesis is mainly constituted of monocrystalline and polycrystalline quartz, plagioclase usually altered to sericite, perthitic microcline, orthoclase and individual euhedral crystals of muscovite or in combination with quartz. The quartz is most commonly present with undulatory extinction, whereas when it is present in fine quartzose aggregates it shows characteristic lobe sutures. Biotite crystals are found always chloritized. Opaque minerals are always present in small amounts. Finally, rock fragments composed of quartz, biotite, muscovite and titanite or rock fragments with clinopyroxene, muscovite and detrital calcite, are contained in the studied clastic sediments.

Other accessory minerals found are: garnet in single euhedral crystals or in rock fragments along with quartz and plagioclase; euhedral single crystals of tourmaline; staurolite altered to fine muscovite; single crystals of kyanite (some times altered to fine muscovite) or kyanite in rock fragments with plagioclase; epidote in single crystals or in rock fragments with garnet and feldspars; zircon; apatite (in single crystals or aggregated with quartz); zoisite; rutile. Especially, in sample X1 amphibole is present as accessory mineral, always in rock fragments with quartz and plagioclase, and clinopyroxene in rock fragments with quartz and small zircon crystals.

\subsection{Geochemistry}

Chemical analysis results are presented in table 4. It is evident that all the samples studied are rich in $\mathrm{SiO}_{2}$. This can be attributed to the high content of quartz, to the fact that the majority of the minerals constituting the samples are silicates and because of the coarse fraction chosen for this study. Pettijohn et al. (1973) and Chuhan et al. (2001) correlate the amounts of $\mathrm{Al}_{2} \mathrm{O}_{3}$ with feldspars, micas and pyroxenes. According to Deer et al. (1998) micas, titanite, rutile, garnet, staurolite, epidote (along with zoisite and clinozoisite), tourmaline and opaque minerals are responsible for the amounts of $\mathrm{TiO}_{2}$ present in the samples.

The total iron $\left(\mathrm{Fe}_{2} \mathrm{O}_{3 \mathrm{t}}\right)$ content can be mainly attributed to micas, amphiboles and opaque minerals, and to a lesser extend to feldspars (Blatt et al. 1972, Pettijohn et al. 1973). The same writers consider that almost the bulk of alkalis in coarse sandstones are concentrated in alkali feldspars and muscovite, with $\mathrm{K}^{+}$generally being more abundant than $\mathrm{Na}^{+}$. The latter seems to apply in the samples studied.

According to Pettijohn et al. (1973) the amounts of $\mathrm{Ca}^{2+}$ are mainly due to the presence of calcite and plagioclases, whereas chlorite and dolomite are responsible for the $\mathrm{Mg}^{2+}$ present. They also consider $\mathrm{Ca}^{2+}$ more abundant than $\mathrm{Mg}^{2+}$, a fact which also applies to the samples studied. Micas, pyroxenes and amphiboles must also be included to the minerals controlling the amounts of $\mathrm{CaO}$ and MgO (Huang 1982, Deer et al. 1998). Because of the absence of detrital calcite and dolomite, plagioclases and micas are responsible for the $\mathrm{CaO}$ and $\mathrm{MgO}$ content in the samples.

$\mathrm{P}_{2} \mathrm{O}_{5}$ and $\mathrm{MnO}$ are present in minor amounts. The former can be attributed to the apatite present and the latter mainly to the tourmaline, garnet and to a lesser extent to the clinopyroxene and epidote present (Deer et al. 1998).

The loss on ignition (LOI) is generally due to the removal of $\mathrm{OH}^{-}$from the crystal lattice of the minerals present, the organic carbon and $\mathrm{CO}_{2}$ from the carbonate minerals. Since carbonate minerals and organic matter are absent, the contained hydroxyl minerals (especially micas) may be considered responsible for the LOI amounts. 


\begin{tabular}{|c|c|c|c|c|c|c|c|c|c|}
\hline & $\stackrel{\substack{\infty \\
\infty}}{\infty} \frac{\infty}{n}$ & â & & & & & & & $q^{2}$ \\
\hline$\frac{n}{x}$ & $\frac{\pi}{\infty}$ & $\frac{m}{8}$ & $\frac{n}{0}=$ & $3 \%$ & : & $\bar{s}$ & & & 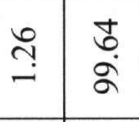 \\
\hline$\frac{\vec{\partial}}{\vec{\lambda}}$ & 竧 & $\frac{9}{b}$ & $: 8$ & $f \frac{n}{0}$ & 3 & $\frac{x}{8}$ & 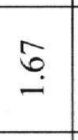 & & 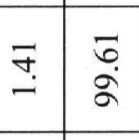 \\
\hline$\stackrel{n}{\vec{\lambda}}$ & $\begin{array}{c}9 \\
\infty \\
\infty\end{array}$ & $\bar{z}$ & $\vec{\circ}$ & & శి & $\stackrel{g}{g}$ & 然 & & \pm \\
\hline$\tilde{x}$ & & : & & & 평 & $\frac{\mathscr{x}}{0}$ & $\stackrel{n}{=}$ & & : \\
\hline$\overline{\bar{\lambda}}$ & & $\frac{\pi}{8}$ & 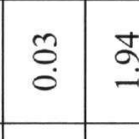 & 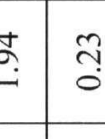 & $\frac{M}{3}$ & \% & $\stackrel{\infty}{=}$ & & 20 \\
\hline$\stackrel{\Xi}{\bar{\lambda}}$ & & : & $\vdots$ & 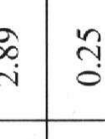 & శ్ & 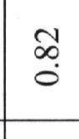 & $\cong$ & & 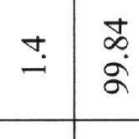 \\
\hline 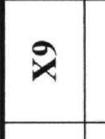 & & 吉 & \begin{tabular}{|l|l}
$:$ & $\infty$ \\
$:$ & 0 \\
\end{tabular} & \begin{tabular}{l}
$: \infty$ \\
\hdashline
\end{tabular} & t & $\Xi$ & I & & 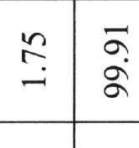 \\
\hline & & $\frac{\circ}{8}$ & & & $\frac{9}{8}$ & & & & $\stackrel{\infty}{=2}$ \\
\hline & & $\tilde{z}$ & & & $\frac{18}{8}$ & & & & $\begin{array}{l} \pm \\
2\end{array}$ \\
\hline & & ב. & & & 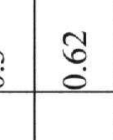 & & & & $\underline{2} \underset{2}{0}$ \\
\hline & & : & & & 9 & & & & $\begin{array}{l}g \\
\underline{2}\end{array}$ \\
\hline & & $\frac{0}{0}$ & & to & $\overline{8}$ & & & & $\begin{array}{ll}q \\
\pm \\
\vdots\end{array}$ \\
\hline & & $\frac{\ddot{0}}{3}$ & 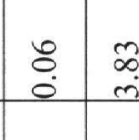 & 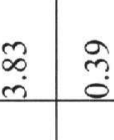 & $\infty$ & & & & $=$ \\
\hline & 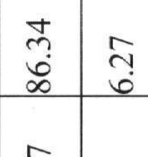 & $\div$ & & 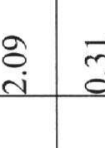 & $:$ & & & & $\pm \underbrace{\infty}_{0}$ \\
\hline & 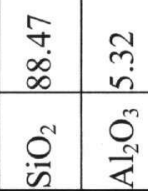 & $\frac{1}{8}$ & $\begin{array}{l}: 8 \\
0 \\
0\end{array}$ & 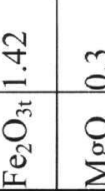 & $\begin{array}{l}\frac{7}{3} \\
8 \\
8\end{array}$ & & & & $\begin{array}{l}\overline{2} \\
\bar{a} \\
\bar{g}\end{array}$ \\
\hline
\end{tabular}


The $\mathrm{SiO}_{2}$ content of the samples studied shows a decreasing trend up to a depth of approximately $90 \mathrm{~m}$, and then increases. The opposite trend is observed for $\mathrm{Al}_{2} \mathrm{O}_{3}, \mathrm{MgO}, \mathrm{CaO}$ and the alkalis. $\mathrm{TiO}_{2}, \mathrm{Fe}_{2} \mathrm{O}_{3}, \mathrm{P}_{2} \mathrm{O}_{5}$ and LOI do not show any distinctive trend, whereas $\mathrm{MnO}$ shows a slight increasing trend with depth.

According to the geochemical classification of Herron (1988) all samples are classified as sublitharenites, except of two (X13 and X14) that are classified as subarkoses (Fig. 2). Pettijohn et al. (1973) consider sublitharenites as lithic sandstones containing 5-25\% labile constituents (i.e. rock fragments and feldspars) and subarkoses as sandstones containing 10-25\% feldspars and limited amounts of rock fragments. The petrographic classification of Folk et al. (1970) is not in complete agreement with the geochemical one of Herron (1988).

\section{Provenance Study}

For the determination of the source of the detrital sediments, the diagrams of Dickinson et al. (1983) and Roser and Korsch (1988) are used.

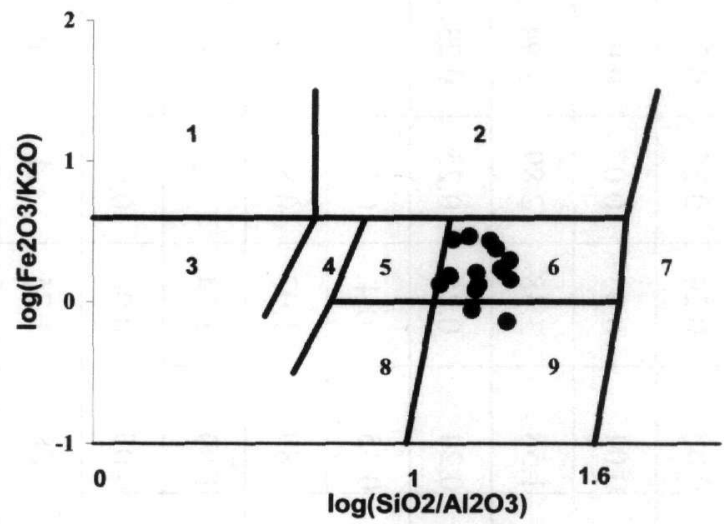

Figure 2 - Geochemical classification of terrigenous sanstones and shales (Herron 1988). 1=Fe-shale, 2 =Fe-sand, 3=shale, 4 =wacke, 5 =litharenite, 6 =sublitharenite, $7=$ quartz arenite, $8=$ arkose $\kappa a \iota ~ 9=$ subarkose

The former has the advantage of incorporating the percentages of monocrystalline and polycrystalline quartz, feldspars and lithic fragments, parameters readily determined for the petrological classification. All the samples fall in the field of recycled orogen, except for sample $\mathrm{X} 1$ that projects in the field of dissected arc (Fig. 3).

The latter makes use of two discriminant functions, based on the major oxide chemical analysis. On this diagram the samples studied project in the field of quartzose sedimentary provenance (Fig. 4). According to Faundez et al. (2002) this source is indicative of quartzose metamorphosed sediments. The field of quartzose sedimentary provenance incorporates detrital sediments typical of passive continental margins (Roser and Korsch 1988). In general, Nesbitt and Young (1982) and Harnois (1988) consider $\mathrm{Na}^{+}, \mathrm{K}^{+}$and $\mathrm{Ca}^{2+}$ useful provenance indicators, on the basis that $\mathrm{Na}^{+}$ and $\mathrm{Ca}^{2+}$ are mobile elements during weathering, whereas $\mathrm{K}^{+}$is immobile and enriched, during transport and deposition, in the clastic load.

Especially, useful for the provenance determination are the heavy minerals, such as garnet, tourmaline, staurolite, kyanite, epidote and zircon. These minerals are considered indexes of low to high grade metamorphic rocks. All these minerals are present as accessory ones in the paragenesis of the studied samples and their presence is consisted with the metamorphic rocks east of the Herso Basin. In addition, the increased amounts of detrital quartz, feldspars, chlorite, muscovite, staurolite and garnet, are indicative of a metamorphic provenance (Moorehouse 1985). 


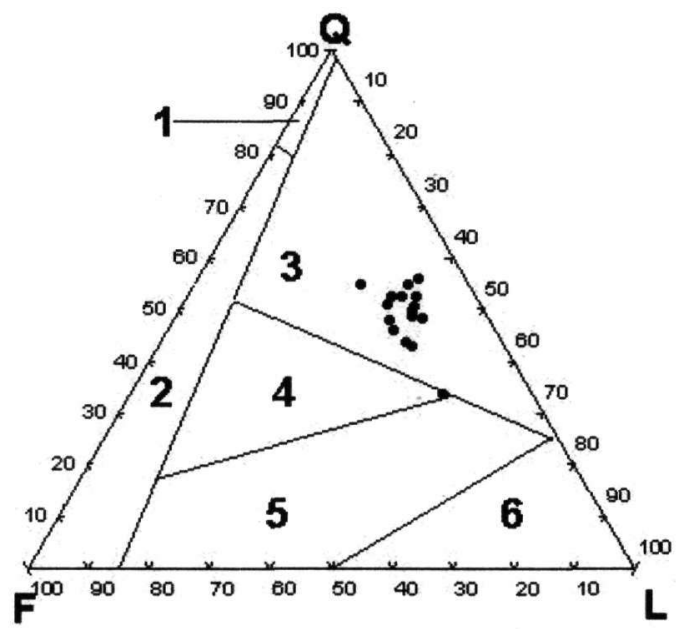

Figure 3 - Provenance discrimination of detrital sediments according to Dickinson et al.

(1983). 1 =craton interior, 2 =basement uplift, 3 =recycled orogen, $4=$ =dissected arc, 5 =transitional arc, $6=$ undissected arc, $Q=$ quartz, $F=$ feldspars, $L=$ lithic fragments

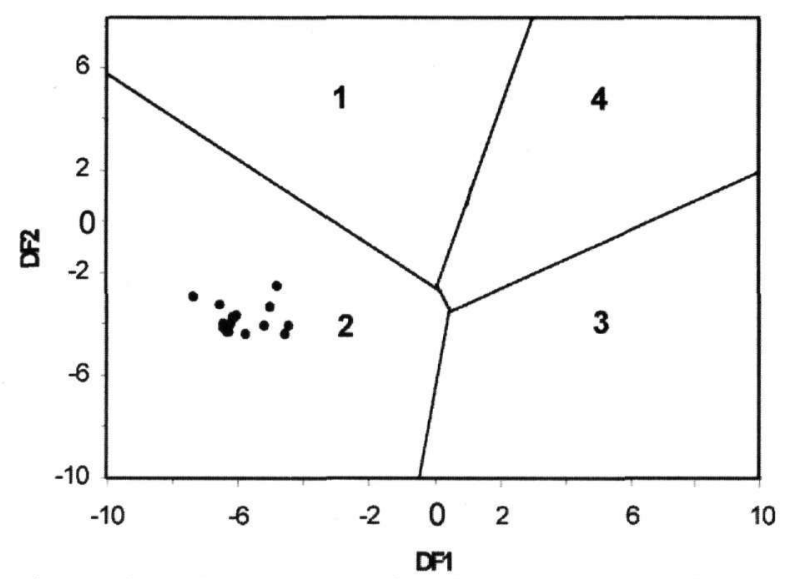

Figure 4 - Discriminant function diagram for the provenance signatures of sandstonemudstone suites (Roser \& Korsch, 1988). 1 =felsic igneous provenance, 2 = quartzose sedimentary provenance, $3=$ mafic igneous provenance, $4=$ intermediate igneous provenance. $\mathrm{DF}_{1}=-1.773 \mathrm{TiO}_{2}+0.607 \mathrm{Al}_{2} \mathrm{O}_{3}+0.76 \mathrm{Fe}_{2} \mathrm{O}_{3 \mathrm{t}}-1.5 \mathrm{MgO}+0.616 \mathrm{CaO}+0.509 \mathrm{Na}_{2} \mathrm{O}-1.224 \mathrm{~K}_{2} \mathrm{O}-9.09$, $\mathrm{DF}_{2}=0.445 \mathrm{TiO}_{2}+0.07 \mathrm{Al}_{2} \mathrm{O}_{3}-0.25 \mathrm{Fe}_{2} \mathrm{O}_{3 \mathrm{t}}-1.142 \mathrm{MgO}+0.438 \mathrm{CaO}+1.475 \mathrm{Na}_{2} \mathrm{O}+1.426 \mathrm{~K}_{2} \mathrm{O}-6.861$

\section{Discussion}

From the petrographic analysis of the samples it is found that these are rich in metamorphic rock fragments and are classified as quartz sandstones according to Dott (1964), as garnet-mica bearing litharenites according to Folk et al. (1970), or as lithic sandstones according to Pettijohn et al. (1973). All the samples are texturally and mineralogically immature.

Their paragenesis is mainly composed of quartz and plagioclase, followed by mica (mainly muscovite) and alkali feldspar (mainly microcline). The accessory minerals include abundant meta- 
morphic minerals (i.e. garnet, tourmaline, staurolite, kyanite, epidote, zircon, apatite, zoisite and rutile), along with few detrital calcite and clinopyroxene. The abundance of plagioclase, compared with that of alkali feldspar, designates intense physical weathering and rapid transport and deposition at small distance along passive continental margins. This tectonic regime is concluded from the percentages of quartz, feldspars and rock fragments in the paragenesis of the samples under study (recycled orogen).

Comparing the petrography of the samples with the petrography of the adjacent rocks, there is readily an affiliation of the former with the metamorphic rocks of the Vertiskos Unit. Especially, the above mentioned accessory metamorphic minerals are indicative of their source. The apatite present in the samples may be attributed to the weathering either of the igneous body at the north of the Basin, or of the metamorphic rocks of the Vertiskos Unit. Tourmaline is considered by Pettijohn et al. (1973) and Blatt (1992) an igneous mineral, but it is not a component of the acid igneous body at the North of the Basin (Christofides et al. 1999), whereas it is a common constituent of the metamorphic rocks of the Vertiskos Unit (Sidiropoulos 1991). The source of the characteristic metamorphic minerals and of fine white mica may be attributed only to the metamorphic rocks of the eastern margin of the Basin.

The absence of detrital carbonate minerals is notable and declares none contribution of clastic load from the carbonate rocks outcropping to the West of the Basin. Also, the absence of sanidine and rock fragments with aphanitic mass designates that the volcanic rocks of the Circum Rhodope Belt did not contribute to the formation of the litharenites studied. The latter could be used as an indication of the streams flow direction through the Basin, though the flow direction of Doiranis River must be considered as the main stream controlling the contribution of clastic load.

The chemical analysis of the samples revealed that these are rich in $\mathrm{SiO}_{2} \cdot \mathrm{K}_{2} \mathrm{O}$ is more abundant than $\mathrm{Na}_{2} \mathrm{O}$ and $\mathrm{CaO}$ more abundant than $\mathrm{MgO}$. The amount of $\mathrm{SiO}_{2}$ in the samples seems to be controlled mainly by quartz, whereas the amount of $\mathrm{Al}_{2} \mathrm{O}_{3}, \mathrm{CaO}, \mathrm{MgO}$ and the alkalis is controlled by feldspars and micas.

\section{Conclusions}

- All samples are generally coarse grained, sand gravels to gravel sands. Their grains present low sphericity and are angular to subangular.

- All samples are texturally and mineralogically immature and were deposited in a fluvial environment.

- They contain quartz as a predominant mineral (58-86\%), plagioclase (7-18\%), mica (2$22 \%$ ), K-feldspar (1-14\%) and the accessory minerals (of metamorphic provenance) garnet, tourmaline, staurolite, kyanite, epidote, zircon, apatite, zoisite and rutile.

- The above mineral paragenesis means the almost exclusive contribution of clastic load from the metamorphic rocks to the East of the Basin and the igneous body to the North.

- These clastic sediments were formed by intense physical weathering of the parent rocks and by rapid transport and deposition of the clastic load at small distance.

- The Herso Basin may be considered part of a passive continental margin (recycled orogen).

\section{References}

Asvesta, A., 1992. The magmatism and its related sedimentation during the first stages of the opening of the ocean basin of Axios in Triassic, PhD Thesis, Aristotle University, Thessaloniki, 436pp.

Blatt, H., 1992. Sedimentary petrology, New York, Freeman \& Co, 250pp. 
Blatt, H., Middleton, G., and Murray, R., 1972. Origin of sedimentary rocks, New Jersey, PrenticeHall, 634pp.

Christofides, G., Koroneos, A., Pe-Piper, G., Katirtzoglou, K., and Chatzikirkou, A., 1999. PreTertiary A-type magmatism in the Serbomacedonian Massif (N. Greece): Kerkini granitic complex, Bull. Geol. Soc. Greece, XXXIII, 131-148.

Chuhan, F.A., Bjorlykke, K., and Lowrey, C.J., 2001. Closed system burial diagenesis in reservoir sandstones: Examples from the Garn formation at Haltenbanken area, offshore MidNorway, J. Sed. Res., 71(1), 15-26.

Cook, H.E., Johnson, P.D., Matti, J.C., and Zemmels, I., 1975. Methods of sample preparation and X-ray diffraction data analysis, Initial reports, Deep Sea Drilling Project, 28, 999-1007.

Deer, W.A., Howie, R.A., and Zussman, J., 1998. An introduction to the rock-forming minerals$2^{\text {nd }} E d$., Essex, Addison Wesley Ltd, 696pp.

Dickinson, W.R., Beard, S.L., and Brakenridge, G.R., 1983. Provenance of North American Phanerozoic sandstones in relation to tectonic setting, Geol. Soc. Am. Bull., 94, 222-235.

Dott, R.H., Jr, 1964. Wacke, greywacke and matrix-What approach to immature sandstone classification? J. Sed. Petrol., 34(3), 625-632.

Faundez, V., Herve, F., and Lacassie, J.P., 2002. Provenance and depositional setting of pre-Late Jurassic turbidite complexes, N. Z. J. Geol. Geophys., 45, 411-425.

Folk, R.L., Andrews, P.B., and Lewis, D.W., 1970. Detrital sedimentary rock classification and nomenclature for use in N. Zealand, N. Z. J. Geol. Geophys., 13, 937-968.

Georgiadis, I.K., 2006. Petrological and geochemical study of the Quaternary detrital sediments of Herso Basin, Kilkis Prefecture, M.Sc. Thesis, Aristotle University, Thessaloniki, 127pp.

Harnois, L., 1988. The CIW index: A new chemical index of weathering, Sed. Geol., 55, 319-322.

Herron, M.M., 1988. Geochemical classification of terrigenous sands and shales from core log data, J. Sed. Petrol., 58, 820-829.

Huang, P.M., 1982. Feldspars, olivines, pyroxenes and amphiboles. In J.B. Dixon and S.B. Weed (eds), Minerals in Soil Environments, 553-595, Soil Sci. Soc. America, Madison, 948pp.

I.G.M.E., 1990. Geological map of Greece, Herso sheet, scale 1:50.000, Athens.

Moorehouse, W.W., 1985. The study of rocks in thin sections, Delhi, CBS Publishers and Distributors, $514 \mathrm{pp}$.

Mountrakis, D., 1985. Geology of Greece, Thessaloniki, University Studio Press, 207pp.

Mountrakis, D., Syrides, G., Polymenakos, L., and Pavlides, S., 1993. The neotectonic structure of the eastern margin of Axios-Thermaikos graben in the area of western Chalkidiki (Central Macedonia), Bull. Geol. Soc. Greece, XXVIII(1), 379-395.

Nesbitt, H.W., and Young, G.M., 1982. Early Proterozoic climate and plate motions inferred from major element chemistry of lutites, Nature, 299, 715-717.

Pettijohn, F.J., Potter, P.E., and Siever, R., 1973. Sand and sandstone, New York, SpringerVerlag, 618pp.

Roser, B.P., and Korsch, R.J., 1988. Provenance signatures of sandstone-mudstone suites determined using discriminant function analysis of major-element data, Chem. Geol., 67, 119 139. 
Sawyer, E.W., 1986. The influence of source rock type, chemical weathering and sorting on the geochemistry of clastic sediments from the Quetico metasedimentary belt, Superior Province, Canada, Chem. Geol., 55, 77-95.

Schultz, L.G., 1964. Quantitative interpretation of mineralogical composition from X-ray and chemical data for the Pierre shale, U.S.G.S. Spec. Paper 391C, 33pp.

Sidiropoulos, N., 1991. Lithology, geochemistry, tectonics and metamorphosis of the Northwestern part of Vertiskos group. The area of Mountain Disoro (Kroussia), North of Kilkis, $P h D$ Thesis, Aristotle University, Thessaloniki, 592pp.

Tsirambides, A.E., 1997. Study of the Quaternary sediments of Doirani basin, Ann. Geol. Pays Hell., 37, 907-919.

Tsirambides, A.E., 2004. Petrology of sedimentary rocks $-2^{\text {nd }}$ Ed., Thessaloniki, University Publications, $261 \mathrm{pp}$.

Tucker, M.E., 2001. Sedimentary petrology: An introduction to the origin of sedimentary rocks- $3^{\text {rd }}$ Ed., Oxford, Blackwell Publishing, 262pp. 